\title{
Current status, Potentials and challenges of Cassava production, processing, marketing and utilization: Evidence from Southern Ethiopia
}

\section{Tesfaye Tadesse ${ }^{1 *}$, Getahun Degu ${ }^{2}$, Ermias Shonga ${ }^{3}$, Shiferaw Mekonen $^{4}$, Temesgene Addis ${ }^{5}$ and Birhanu Yakob ${ }^{6}$}

\author{
${ }^{1}$ Horticulturist, Hawassa Agricultural Research Center, P.O.Box 06. \\ ${ }^{2}$ Socio-economist, Hawassa Agricultural Research center. \\ ${ }^{3}$ Entomologiest and Nematologiest, Hawassa Agricultural Research center. \\ ${ }^{4}$ Pathologiest, Hawassa Agricultural Research Center. \\ ${ }^{5}$ Entomologiest and Nematologiest, Hawassa Agricultural Research center. \\ ${ }^{6}$ Food science and post harvest handling, Hawassa Agricultural Research Center.
}

Article No.: 021313457

DOI: 10.15580/GJAS.2013.4.021313457

Submitted: $13 / 02 / 2013$

Accepted: 22/04/2013

Published: 29/04/2013

${ }^{*}$ Corresponding Author

Tesfaye Tadesse

E-mail: tesfayet2@yahoo.com

Phone: +251462200084

$+251911440971$

Keywords:

farming system, Woreda, Zone, scale insect
The paper provides primary information on the status, potentials and challenges of cassava production, utilization and marketing major cassava growing areas of southern Ethiopia. The study was conducted in five purposively selected sample Woredas / districts of SNNPR, Amaro, Kindokoyesha, Gofa, Arbamench Zuria and Konso based on cassava production potential and accessibility in consultation with Zonal and Woreda bureau of agriculture. A total of 200 sample respondents, 40 from each district were selected and interviewed using structured questionnaire. The study also considered information from secondary sources The data collected from the sample respondents and secondary sources were analyzed using descriptive statistic and use of statistical software package SPSS, 2011. The result indicated that cassava stands first in both production and productivity followed by sweet potato and maize in belge (short rainy season) while during Meher (long rainy season) the reverse was observed. The mean land holding (ha) of a household in the study areas were $0.93,0.46,1.22,0.56$ and 0.73 for Amaro, Kindo Koyisha, Demba Gofa, Konso and Arbamench respectively. The overall mean of land holding in the study area was 0.78 ha. The mean land holding of sample household allocated for cassava production in the study area was 0.20 ha. Area allocated for improved and local cultivar cassava average for the study area is 0.19 and 0.30 ha respectively. Land preparation for all crops under cassava farming system was carried out by using outdated and labor intensive tools such as hoe $(66 \%)$ and ox plough $(33 \%)$ of sample farmer's average for the five districts. Income generated from cassava was by selling fresh cassava root from the farm and/or the nearby local market. In the same way, processed cassava products especially cassava chips and flours were consumed and sold in the study area. The quality of the planting material that the farmers were using had average quality as to $52 \%$ of sampled farmers and $36 \%$ using high quality planting materials. Most of the farmers obtain planting materials from their own savings but few had gotten from relatives, friends and other sources. The two improved varieties introduced to the farmers were kello (44/72 red) and Qulle (104/72 Nigerian red). The adoption rate for the improved varieties by the sampled farmers in the study area in average was only $30 \%$. There were some constraints in cassava production areas. Among which insect pest invasion, lack of early maturing variety, shortage of land, low moisture stress and low market demand and/or price were among the most important ones. Therefore, labor saving farm implements, management of cassava scale insects and existing post harvest processing equipments needs to be improved. Development and demonstration of early maturing cassava varieties is also a pertinent area to contribute to solve the existing problems of cassava producing areas. 


\section{INTRODUCTION}

Cassava (Manihot esculenta Crantz) is the fourth most important crop for farmers in tropics after rice, wheat and sugar, consumed by up to a billion people globally (FAOSTAT, 2010). Cassava is a perennial woody shrub with an edible root, which grows in tropical and subtropical areas of the world. Cassava originated from tropical America and was first introduced into Africa in the Congo basin by the Portuguese around 1558. Today, it is a dietary staple in much of tropical Africa. It is rich in carbohydrates, calcium, vitamins $\mathrm{B}$ and $\mathrm{C}$, and essential minerals. However, nutrient composition differs according to variety and age of the harvested crop, and soil conditions, climate, and other environmental factors during cultivation.

In sub-Saharan Africa (SSA) cassava is mainly a subsistence crop grown for food by small-scale farmers who sell the surplus. It grows well in poor soils with limited labor requirements. It provides food security during conflicts when the invader cannot easily destroy or remove the crop, since it conveniently grows underground. Cassava is usually intercropped with vegetables, plantation crops (such as coconut, oil palm, and coffee), yam, sweet potato, melon, maize, rice, groundnut, or other legumes. The application of fertilizer remains limited among small-scale farmers due to the high cost and lack of availability. Roots can be harvested between 6 months and 3 years after planting. Apart from food, cassava is very versatile and its derivatives and starch are applicable in many types of products such as foods, confectionery, sweeteners, glues, plywood, textiles, paper, biodegradable products, monosodium glutamate, and drugs. Cassava chips and pellets are used in animal feed and alcohol production (IITA, 2009)

In Ethiopia, cassava grows in vast areas mainly in Southern Region. According to Feleke (1997), cassava was introduced by some NGOs to drought prone areas of southern part of the country such as Amaro, Gamogoffa, Sidama, Wolayta, Gedeo primarily to fill the gap for subsistence farmers due to failure of other crops as a result of drought. In these areas, farmers usually grow cassava in small irregular scattered plots either sole or intercropped mainly with taro, enset, maize, haricot bean and sweet potato. The average total coverage and production of cassava per annum in Southern region of Ethiopia is 4942 hectars with the yield of 53036.2 tonnes (SNNPR, BoA, 2000). Although its first introduction in to the country is not yet known, the crop had been growing in south, south west and western part of Ethiopia for several years (Teshome et.al., 2004). Its use as a potential food crop in Ethiopia has been appreciated since 1984 famine (Amsalu, 2006).
Cassava is one of the most important food crops that constitute a considerable portion of the daily diet of the people and also serves as a major source of carbohydrate in Southern Ethiopia. Despite its importance cassava production in Ethiopia has different constraints and opportunities. It is mainly cultivated by small resource poor farmers on smallholding plots of land. It is both a food security crop and a source of household income. It is increasingly becoming a source of industrial raw material for production of starch, ethanol, waxy starch, bio-plastics, glucose, bakery and confectionery products, glue among others.

Despite its great potential to make different food recipes, in Ethiopia most of the cassava produce is consumed only by boiling the tuber and supplied with sauce of hot pepper/chili (personal observation).

On-farm postharvest handling and storage of cassava is still traditional; with cassava chipped and dried on the bare ground, stored in rudimentary structures such as woven baskets, traditional granaries and heaped on the floor in corners of living houses. These conditions favor the easy development of storage pests and microbial contaminants such as Aspegilus flavus (aflatoxins) among others. Thus, survey was conducted on five cassava growing areas of southern Ethiopia to document and transfer of knowledge on current status, potentials and challenges on cassava farming system of southern Ethiopia.

\section{METHODOLOGY}

\section{The study area}

The study was conducted in five purposively selected sample Woredas / districts of SNNPR, Amaro, Kindokoyesha, Gofa, Arbamench Zuria and Konso based on cassava production potential and accessibility in consultation with Zonal and Woreda bureau of agriculture. Two sample kebeles was also selected purposefully from each woreda respectively.

The Southern Nations, Nationalities and People's Regional State (SNNPRS) is located in the Southern and Southwestern part of Ethiopia bordering Kenya in the South, the Sudan Republic in the South West, Gambella Region State in the Northwest and Oromiya Regional State in the North and East. The region covers an area of $105,887 \mathrm{~km}^{2}$ which is about 10 percent of the total area of the country. The population of the region was estimated to be 16.9 million of which 93 percent is rural and 7 percent is urban dweller. The average population density of the region is 159 persons /sq $\mathrm{km}$ (CSA, 2010). The sampled areas for this study; among the major cassava growing areas of the region are shown in table 1. 


\begin{tabular}{|c|c|c|c|c|c|c|}
\hline Zone & $\begin{array}{l}\text { Woreda/Di } \\
\text { strict }\end{array}$ & Kebele & $\begin{array}{l}\text { Altitude } \\
\text { (masl) }\end{array}$ & Latitude & Longitude & $\begin{array}{l}\text { Farming } \\
\text { System }\end{array}$ \\
\hline \multirow[t]{4}{*}{ Gemu Goffa } & $\begin{array}{l}\text { Demba } \\
\text { Goffa }\end{array}$ & $\begin{array}{l}\text { Zenga } \\
\text { Dormele }\end{array}$ & 1297 & $06^{\circ} 22^{\prime} 335^{\prime \prime}$ & $036^{\circ} 58^{\prime} 306^{\prime \prime}$ & Mixed Farming \\
\hline & & $\begin{array}{l}\text { Docha } \\
\text { Dembela }\end{array}$ & 1246 & $06^{\circ} 25^{\prime} 559^{\prime \prime}$ & $\begin{array}{l}037^{\circ} \\
02 ' 655^{\prime \prime}\end{array}$ & Mixed Farming \\
\hline & $\begin{array}{l}\text { Arbaminch } \\
\text { Zuria }\end{array}$ & Chano Chelba & 1223 & $06^{\circ} 06^{\prime} 415^{\prime \prime}$ & $037^{\circ} 34^{\prime} 816^{\prime \prime}$ & Mixed Farming \\
\hline & & Chano MIlle & 1215 & $06^{\circ} 06^{\prime} 656^{\prime \prime}$ & $037^{\circ} 06^{\prime} 415^{\prime \prime}$ & Mixed Farming \\
\hline \multirow{4}{*}{$\begin{array}{l}\text { Segen } \\
\text { Hizboch }\end{array}$} & Konso & Mecheke & 1776 & 0517’496”' & $037^{\circ} 23^{\prime} 734^{\prime \prime}$ & Mixed Farming \\
\hline & & Gaho & 1826 & 05¹7’802" & $037^{\circ} 22^{\prime} 606^{\prime \prime}$ & Mixed Farming \\
\hline & Amaro & Jijola & 1477 & N05³9'58.6" & E37054'23.9" & Mixed Farming \\
\hline & & Dano Bulto & 1548 & N0543'21.7" & E37054'29.7" & Mixed Farming \\
\hline Wolayta & $\begin{array}{l}\text { Kindo } \\
\text { Koysha }\end{array}$ & Molticho & 1266 & N06 '54'23.8”' & $\begin{array}{l}\text { E } 037 \\
\text { '21'16.1', }\end{array}$ & Mixed Farming \\
\hline
\end{tabular}

Source, Survey 2011

\section{Sampling procedure}

For this study both primary and secondary data sources were used. The primary data was collected from sample farmers in the study area. Sample respondents were drawn using simple random sampling from the list of households obtained from each rural kebele administrations. While sex of the household heads were considered to ensure representation of female headed households in the sample. A total of 200 sample respondents, 40 from each district, were selected and interviewed using structured questionnaire. The study also considered information from secondary sources such as research centers and Woreda and Zonal Agriculture and Rural Development Offices regarding cassava production and marketing, and various literatures were thoroughly reviewed. In order to assess the situation of insect pests and disease problems on the crop in the region; sampling was made at 5 kilometer intervals and both plant and pest samples were taken at the same time.

\section{Data Collection}

This study was conducted using information collected from farmers and others involved in production and marketing of cassava in the study area. For this study both formal interview technique using structured questionnaires and key informant discussions using checklists were employed. A team of researchers from different disciplines were participated to undertake the formal survey and training for enumerators was provided. During data collection, close supervision were carried out by researchers.

\section{Data Analysis}

The data collected from the sample respondents and secondary sources were analyzed using descriptive statistic and use of statistical software package such as SPSS.

\section{RESULT AND DISCUSSION}

\section{Major crops grown in cassava based farming System}

The major crops grown in the cassava based farming systems, area in ha; production in qt $(100 \mathrm{~kg})$ and productivity (Qt) were depicted in table 1and 2. Cassava stands first in both production and productivity followed by sweet potato and maize in belge (short rainy season). 
During Meher (long rainy season) the reverse was observed (Table 2). The result indicated that cassava requires low moisture content of the soil for higher yield than the other crops under comparison.

\section{Household land ownership and preparation}

The major crops produced under cassava farming system were Maize, teff, sweetpotato, cassava, common bean, sorghum and enset. They are produced for both home consumption and income generation. As indicated in table 2 , cassava got the line share as a source of food and income generation followed by maize, teff and sweetpotato. In the cassava farming system crop rotation was essential practice according to $72 \%$ of the farmers in the study area across the districts. The pattern of rotation is mainly depend on the main crops and used pulses; root crops depend on Belg and Meher.

Table 2. Present distribution of sample respondents by their Land holding, 2011

\begin{tabular}{|c|c|c|c|c|c|c|c|c|c|c|c|c|}
\hline \multirow[t]{2}{*}{ Characteristics } & \multicolumn{2}{|c|}{ Amaro } & \multicolumn{2}{|c|}{\begin{tabular}{|l|} 
Kindo \\
koyesha
\end{tabular}} & \multicolumn{2}{|c|}{ Demba Gofa } & \multicolumn{2}{|c|}{ Konso } & \multicolumn{2}{|c|}{ Arbamench } & \multicolumn{2}{|c|}{ Total } \\
\hline & $\begin{array}{l}\text { Mea } \\
\mathrm{n}\end{array}$ & SD & $\begin{array}{l}\text { Mea } \\
n\end{array}$ & SD & $\begin{array}{l}\text { Mea } \\
\mathrm{n}\end{array}$ & SD & Mean & SD & Mean & SD & $\begin{array}{l}\text { Mea } \\
\mathrm{n}\end{array}$ & SD \\
\hline $\begin{array}{l}\text { Total crop cultivated } \\
\text { land this year (ha) }\end{array}$ & 0.93 & 1.73 & 0.46 & 0.50 & 1.22 & 2.20 & 0.56 & 1.20 & 0.73 & 0.89 & 0.78 & 1.44 \\
\hline $\begin{array}{l}\text { Area allocated for } \\
\text { cassava this year (ha) }\end{array}$ & 0.24 & 0.33 & 0.19 & 0.15 & 0.27 & 0.18 & 0.14 & 0.15 & 0.15 & 0.10 & 0.20 & 0.21 \\
\hline $\begin{array}{l}\text { Area for improved } \\
\text { cassava (ha) }\end{array}$ & 0.08 & 0.07 & 0.38 & 1.06 & 0.19 & 0.13 & 0.01 & 0.01 & 0.12 & 0.07 & 0.19 & 0.58 \\
\hline Area for local cassava & 0.16 & 0.19 & 0.88 & 1.79 & 0.42 & 0.59 & 0.13 & 0.14 & 0.10 & 0.07 & 0.30 & 0.77 \\
\hline $\begin{array}{l}\text { Yield of cassava } \\
\text { tones/ha }\end{array}$ & 1.56 & 2.12 & 2.32 & 7.12 & 2.69 & 9.47 & 2.21 & 4.40 & 2.77 & 17.4 & 2.31 & 8.10 \\
\hline Plot 1 size in (ha) & 0.81 & 0.77 & 0.50 & 0.47 & 0.76 & 0.94 & 0.26 & 0.20 & 0.86 & 0.50 & 0.64 & 0.66 \\
\hline
\end{tabular}

Table 2 continues

\begin{tabular}{|l|l|l|l|l|l|l|l|l|l|l|l|l|}
\hline Plot 2 size in (ha) & 0.31 & 0.26 & 0.49 & 0.64 & 0.38 & 0.37 & 0.21 & 0.15 & 0.47 & 0.24 & 0.37 & 0.37 \\
\hline Plot 3 size in (ha) & 0.13 & 00 & 0.25 & 00 & 0.28 & 0.33 & 0.31 & 0.26 & 00 & 00 & 0.27 & 0.24 \\
\hline Plot 4 size in (ha) & 0.13 & & & & & & & & & & & \\
\hline
\end{tabular}


The land preparation method is mainly using farm outdated and labor intensive tools such as hoe $(66 \%)$ and ox plough $(33 \%)$ of sample farmer's average for the five districts. While the time (days) spent and the money expended for land preparation and weeding for men, women and children indicated in Fig 1. Larger number of days was required for preparation of land by children followed by women. But land preparation was not done by a given person The business was carried out by integrating men, women and children efforts. Therefore, on average, 10-50 days were required for land preparation based on soil type and agro-ecological conditions.

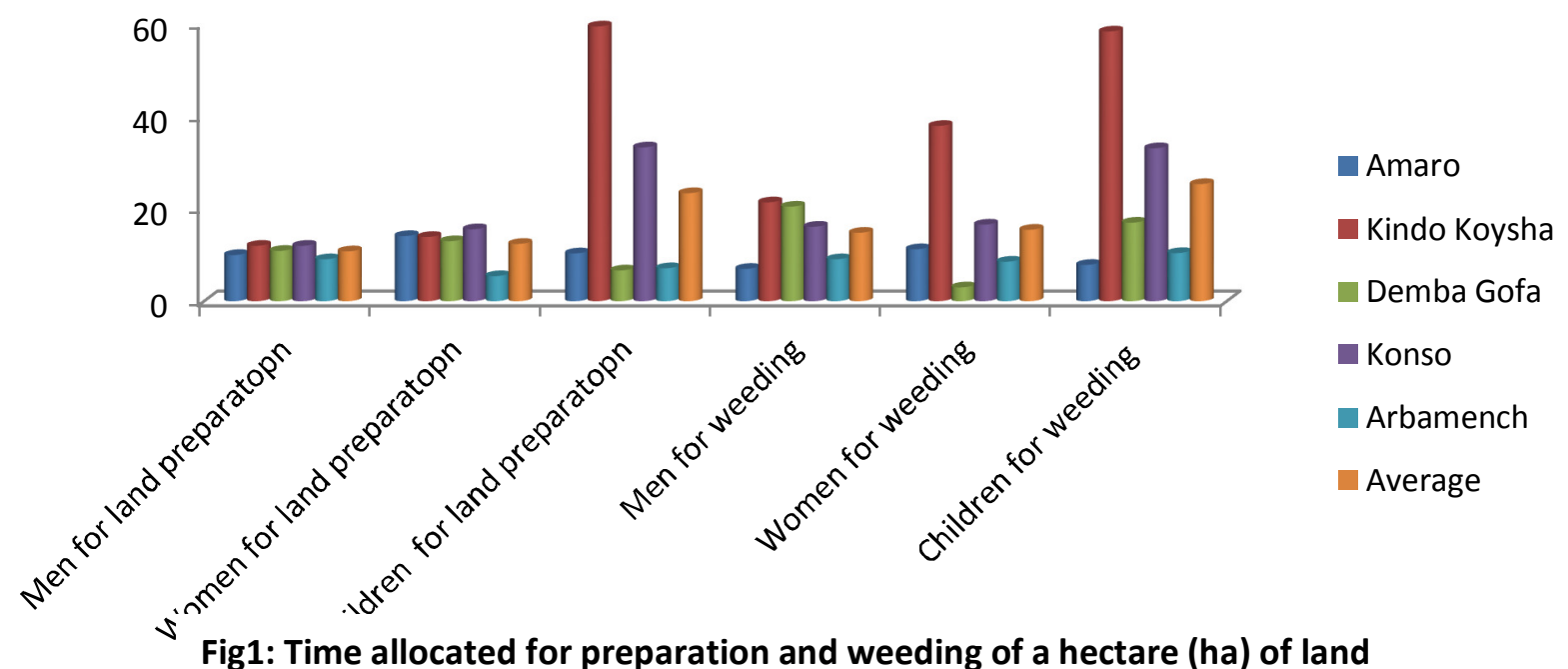

\section{Purpose and system of Crop production}

The major crops produced under cassava farming system were Maize, tef, sweet potato, cassava, common bean, sorghum and enset. They are produced for both food and income generation. As indicated in table 3, cassava got the line share as a source of food and income generation followed by maize, tef and sweet potato. In the cassava farming system, crop rotation was an essential practice according to $72 \%$ of the farmers in the study area across the districts. The pattern of rotation mainly depends on the main crops and used pulses; root crops depend on Belg and Meher.

Table 3: Major crops grown and use in the study area in cassava based farming system

\begin{tabular}{|l|l|l|l|}
\hline Crop type & $\begin{array}{l}\text { Rank for food (N of } \\
\text { farmers) }\end{array}$ & $\begin{array}{l}\text { Rank for income (N of } \\
\text { farmers) }\end{array}$ & $\begin{array}{l}\text { Rank for Both (N of } \\
\text { farmers) }\end{array}$ \\
\hline Maize & $102(27 \%)$ & $200(53 \%)$ & $74(20 \%)$ \\
\hline Sorghum & $49(43 \%)$ & $34(30 \%)$ & $31(27 \%)$ \\
\hline Tef & $55(25 \%)$ & $96(44 \%)$ & $69(31 \%)$ \\
\hline S. potato & $200(56 \%)$ & $87(24 \%)$ & $69(20 \%)$ \\
\hline Common bean & $45(15 \%)$ & $200(68 \%)$ & $49(17 \%)$ \\
\hline cassava & $200(58 \%)$ & $60(18 \%)$ & $21(29 \%)$ \\
\hline Enset & $28(41 \%)$ & $19(30 \%)$ & $82(24 \%)$ \\
\hline
\end{tabular}

Source, Survey 2011

Income generated from cassava was by selling fresh cassava root from the farm and/or the nearby local market. In the same way processed cassava products especially cassava chips and flours were consumed and sold in the study area according to $81 \%$ and $80 \%$ of sampled farmers respectively. 


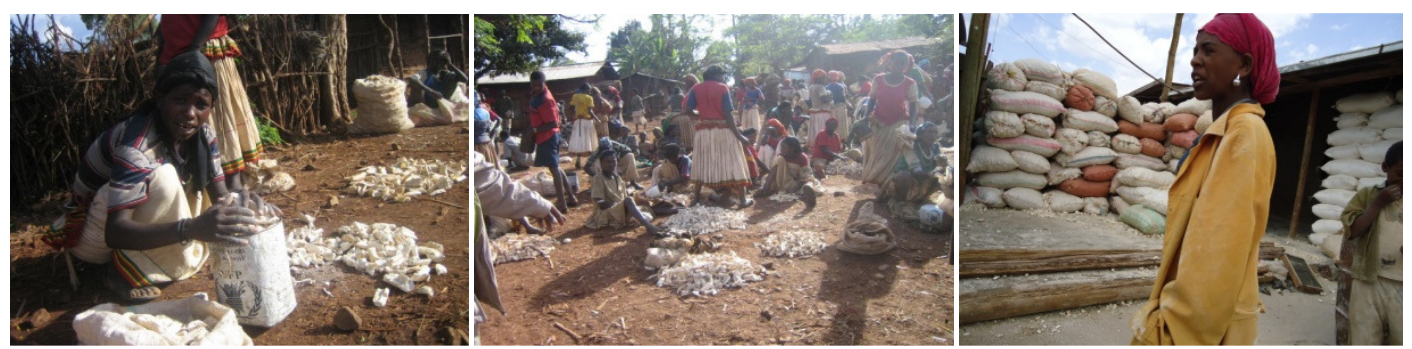

Fig 2: From left to right Cassava in Konso open marke(1\&2), Cassava flour Wolayita Sodo milling house

\section{Cassava Production}

\section{Cassava production target districts}

In cassava based farming system, the proportion of cassava growing for all districts is approximately many: $50-75 \%$ according to $35 \%$ of the sampled farmers. Farmers have also access to planting material of $92 \%$ of the farmers in all districts. Hence the quality of the planting material is average according to $52 \%$ of sampled farmers for all districts and some of them also rated high quality of $36 \%$ of the source of planting material when there is no sacristy, $67 \%$ of the farmers responded own field, from friends $18 \%$ and family/ neighbors $12 \%$. While the source of planting material when there is scarcity, $46 \%$ of the farmers said from friends, $29 \%$ from family/neighbor and from own field (14\%). Meanwhile, farmers select variety (ies) for planting according to $76 \%$ of sampled farmers (Table 10). The two improved varieties introduced to the farmers were kelo (44/72 red) and Kule (104/72 Nigerian red). The adoption rate for the improved varieties by the sampled farmers in the study area in average was only $30 \%$.

The agricultural technologies are generated, verified and evaluated by agricultural research centers on farmer's fields. After on-farm verification and proper evaluation, the National Variety Release Committee (NVRC) officially releases varieties. Package of recommendations for farmers usually developed by the respective agricultural researchers and extension annually.

Table 6: Characteristics of improved cassava varieties

\begin{tabular}{|l|l|l|l|l|}
\hline Type of variety & $\begin{array}{l}\text { Rainfall } \\
(\mathbf{m m})\end{array}$ & Altitude(m) & \multicolumn{2}{|c|}{ Yield qt/ha } \\
\cline { 3 - 5 } & & & On-station & On-farm \\
\hline Kelo (44/72 red) & $980-1398$ & 1200 & 281 & 271 \\
\hline $\begin{array}{l}\text { Kule (104/72 Nigeria } \\
\text { red) }\end{array}$ & $980-1398$ & $\begin{array}{l}1200- \\
1800\end{array}$ & 272 & 241 \\
\hline
\end{tabular}

Source: Tesfaye et al. 2012

Some of the constraints in cassava production as to the proportion of the respondents in the study areas, were insect pest invasion $30 \%$, lack of early maturing variety $(20 \%)$, shortage of land $(18 \%)$, moisture stress $(17 \%)$ and low market demand and/or price (15\%). As to the comments of farmers at the study areas for solving the problems created in the cassava production were Cropping pattern and variety preference

Cassava usually is a sole crop as well as intercropped /mixed with maize, sorghum, finger millet, haricot bean introduction (development) of improved cassava production and productivity practices $(17 \%)$, improved variety $(30 \%)$, Processing device $(29 \%)$, pest control methods (18\%), and use of fertilizer/compost (13\%).

and sweet potato. Farmers do not use fertilizer for cassava. White fleshed and short type cassava varieties were preferred for home consumption as of the sampled farmers. Those varieties were considered by the 
respondent as sweeter and palatable while prepared by local dish. The varieties with the characters such as shorter height, long storage root, red skin color and bugger size were preferred for market because of their higher flour contentment after drying. Accordingly the problems of the local cultivars were late maturity, low yield and Susceptibility to pests specifically scales insect.

\section{Cassava pest incidence}

The most important insect pests attacking cassava in the study areas were cassava scale insect (Aonidoytilus albus), Cassava green mite (Mononychellus tanajoa) and Red spider mite (Tetranychus spp). The predatory beetle Cybacphalus spp. was associated with the scale insect in most of the surveyed areas as indicated by Ermias, et.al. Among the three, cassava scale insect was the most serious one and its severity was high at Amoro, followed by Kido Koyisha and Arbamich zuria, respectively. In Cassava growing areas of the country farmers were reported the yield reduction due to stunted growth and yellowing of cassava leaves at early stage of development. This might be attributed to some of cassava diseases like virus. They also appeal for the existence of unknown insect pests on the stems of cassava plant. Cassava scale (Aonidomytilus albus) (Cockerel) (Hem: Diaspididae) was reported for the $1^{\text {st }}$ time in 2001 at Amaro. It was affecting the production and productivity of the cassava in southern Ethiopia, Amaro especially at wereda (Mesele et al., 2007).

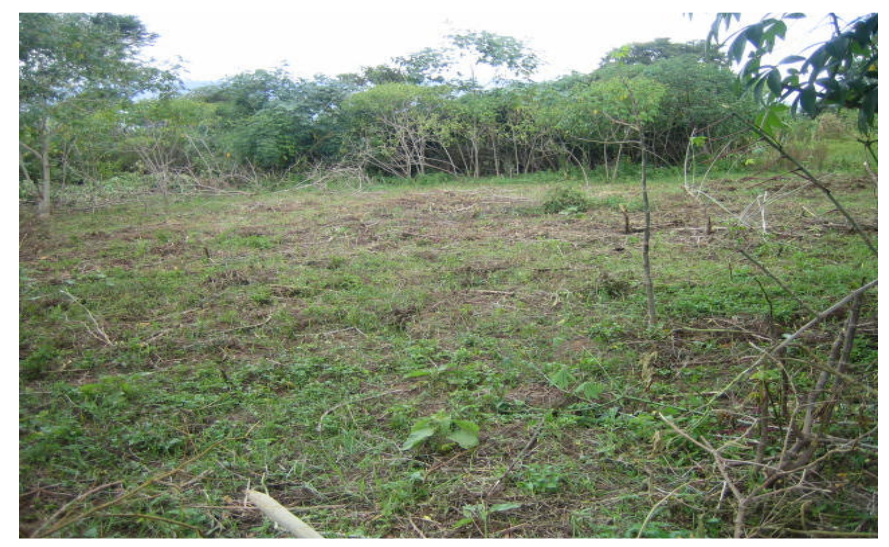

Photo 3: Cassava scale insect invasion: left farm abandoned due to cassava scale insect; right cassava scale insect incidence

\section{CONCLUSION}

This study has provided primary information in cassava producing districts of the southern region. Cassava plays
Farmers in the study area were not aware of the Cassava Scale Insect (CSI). $73 \%$ of the farming community and only $27 \%$ knows the insect. The source of information regarding CSI is from other farmers (65\%) and from agricultural extension workers (28\%). Farmers recognize that the occurrence of insect symptoms is on the crop stem- $72 \%$ of the sampled farmers knew this; on leaves $(16 \%)$ and on storage roots (12\%). $50 \%$ of the farmers reported that the insect spread by planting materials and $22 \%$ reported that the insect move by themselves. Attempt to control the insect was $61 \%$ of the respondents and the remaining $39 \%$ did not try to control the insect. The method of control is mainly by uprooting the diseased plant,and planting disease free looking planting material $(20 \%)$ and then burning infected debris of the plant $(13 \%)$.

The effectiveness of using disease free planting material is partly effective ( $41 \%)$, very effective (35\%) and not effective $(28 \%)$. The effectiveness of disease free planting material is very effective $(28 \%)$ of the sampled farmers for the five districts. $73 \%$ of the farmers reported that the uprooting of the diseased plant is not effective and partly effective (18\%). The effectiveness of burning infected plants is not effective as of $(100 \%)$ famers. The above control methods were recommended by other farmers $(53 \%)$ and $27 \%$ by agricultural extension staffs (Table 8). It was observed that cassava scale insect causes complete devastation of cassava field and the farmers' abandon the field as shown in photo 3 .

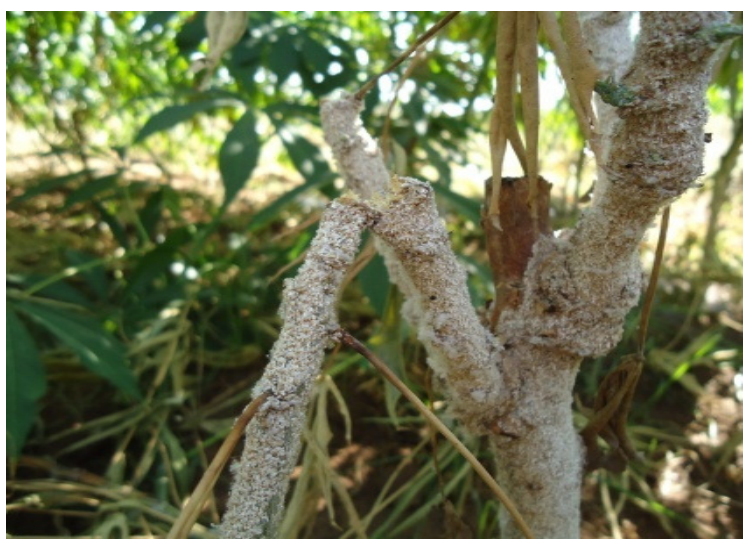

an important role in the region for consumption, animal feed and source of income to many rural and urban households. However, there are problems regarding cassava scale insect specifically at Amaro especially at 
woreda and Kindo-koyesha. Cassava scale insect that feed on the stem and stem buds is the most important one. Defoliation, die back and complete crop yield loss resulted due to the pest. The constraints of cassava production such as late maturity and shortage of high yielding cultivars should receive due attention.

\section{RECOMMENDATIONS}

This paper provides primary information on production, productivity, utilization and marketability of cassava to improve the livelihood of the farming community as well as to improve the multiplication and distribution of farmerpreferred varieties in marginal areas; improve extension services, linkages with other international agencies such as CIAT and IITA. Improve processing technologies for cassava flour to achieve desired attributes, improve linkages between farmers and processors in urban centers in order to promote value addition activities such as use of cassava in large scale millings, bakeries and factories extract starch believed that improve cassava marketing. The need to diversify consumable cassava products, improve the quality and standardization of existing products through improved technologies, and develop a recipe cassava manual for use by nutrition extensions will have a great contribution in cassava utilization and marketing. Further more research should focus on the five the most important problems such as cassava scale insect, lack of early maturing varieties, cassava fresh and processed product markets, moisture stress and land shortage. The existing processing technologies are also inefficient and need to be improved so that resulting products are made more attractive and competitive in the market. The cassava scale insect issues also need to be addressed to ensure farmers get high yield for their cassava.

\section{ACKNOWLEDGEMENT}

The authors would like to thank South Agricultural Research Institute, Hawassa Agricultural Research Center for facilitating the survey and other cassava research works. Our acknowledgment extends to East African, Agricultural Productivity Program for funding cassava research activities in general and cassava survey in particular.

\section{Author Profile}

Tesfaye Tadesse received his BSc from Haramaya University, formerly called Alemaya University, in plant science and his MSC in plant science specialization in Horticulture from Hawassa university formerly called Debub university. He is working for South Agricultural Research Institute, Hawassa Agricultural Research Center as a horticulturist especially on crop improvement of root and tuber crops since June 2003. He has visited different African and European countries to take short term trainings and attend workshops. He has 15 publications as sole author and co-author with colleagues on different journals, proceedings, newsletters and books.

\section{REFERENCE}

Amsalu N (2006). Phenotypic Diversity of Cassava (Manihot esculenta Cranz.) in Ethiopia. Proceedings of the $12^{\text {th }}$ Annual Conference of the CroP Science Society of Ethiopia, 22-24 May 2006, Addis Ababa, Vol. 12, Pp 23-29.

CSA (Central Statistical Authority).2010. Agricultural sample survey 2009/20010. Report on area and production for major crops (Private peasant holding, main season). Statistical Bulletin A.A, Ethiopia.

Ermias S, Temesgen A, Mesele G and Tesfaye T (2012). Cassava Scale: A New Threat for a Food Security Crop in Ethiopia. The African Journal of Plant Science and Biotechnology 6(Special issue1), pp 80-83.

Eyasy $E$ (1997). Soil fertility management and nutrient balance in kindokoysha farms. A case study in North Omo, Southern Ethiopia, Alemayehu Konde and Jan Scoons (eds.). FRP Technical Pamphlet No. 15, Addis Abeba, Ethiopia.

Feleke A (1997). Participatory rapid rural appraisal of Abaya Woreda, North Omo, FARM Africa, Addis Ababa, Ethiopia.

Food and Agricultural Organization (FAO) STAT, 2010. Statistical data base of the food and agricultural organization of the united nations available at http://faostat.

IITA (International Institute of Tropical Agriculture ), 2009. http://www.iita.org/cassava Oyo State, Nigeria

IITA (International Institute of Tropical Agriculture ), 1989. Cassava in Tropical Africa: Reference manual provisional edition for the 1989 Group Training Course, Intec Printers Limited, Ibadan, Nigeria.

Mbwika JM, Ntawuruhunga $\mathrm{P}$, KariukiC, and MakhokaA (2002). Strategies for transforming cassava subsector to ensure food security, income generation and economic growth in East, Central and Southern Africa. Proceedings of the regional workshop on improving the cassava sub sector held at International Center for Research in Agro-forestory (ICRAF), Nairobi, Kenya on $8^{\text {th }}-12^{\text {th }}$ April 2002.

Mesele G, Ntawuruhunga P, Teshome A and Legesse H (2007). A minor insect pest becoming major threat of cassava production in Amaro, Southern Ethiopia: Newsletter of the southern Africa root crops research network (SARRNET) \& the East Africa root crops Research Network (EARRNET). Vol. 10 issue 2. pp21-23.

Nweke FI (1992). Cassava: A cash crop in Africa. A collaboration study of cassava in Africa. Working paper No. 14. In proceeding of the eighth Triennial Symposium of the International Society for Tropical Root crops - Africa Branch (ISTRC - AB).pp. 104 109. 
Southern Nationalities and Peoples Region, Bureau of Agriculture (SNNPR, BoA), 2000. Basic Agricultural Information Planning and programming Service, Hawassa, Ethiopia.
Tesfaye T, Daniel M, Fikre H, Molalish P, Legesse $\mathrm{H}$ and M G (2012). Cassava production and utilization Manual, Tom publisher, Hawassa, Ethiopia.

Cite this Article: Tadesse T, Degu G, Shonga E, Mekonen S, Addis T and Yakob B (2013). Current status, Potentials and challenges of Cassava production, processing, marketing and utilization: Evidence from Southern Ethiopia. Greener Journal of Agricultural Sciences, 3(4), 262-270, http://doi.org/10.15580/GJAS.2013.4.021313457. 